\title{
Küberkiusamise fenomeni tajumine Eesti õpilaste seas: sooline võrdlus kiusamise kriteeriumite ja liikide alusel
}

\author{
Karin Naruskov ${ }^{\mathrm{a} 1}$, Piret Luik ${ }^{\mathrm{a}}$ \\ a Tartu Ülikooli haridusteaduste instituut
}

\begin{abstract}
Annotatsioon
Küberkiusamise sügavama mõistmise, sealhulgas mõõtmise seisukohalt on oluline teada, kuivõrd sarnaselt või erinevalt poisid ja tüdrukud küberkiusamise fenomeni tajuvad. Teema põhjalikuma käsitlemise vajalikkusele viitab ka asjaolu, et varasemad küberkiusamise valdkonnas tehtud soolise võrdluse uuringud on andnud üsna vastuolulisi tulemusi. Uurimistöö eesmärk on võrrelda poiste ja tüdrukute vahelisi erinevusi küberkiusamise fenomeni tajumisel kiusamise kriteeriumite ja liikide alusel. Uuringus osales 336 Eesti õpilast vanuses 11-17 eluaastat: 163 tüdrukut ja 173 poissi. Instrumendina kasutati Euroopa projektis COST Action IS0801 valminud ankeeti. Andmeid analüüsiti vorrdlustestide, täpsemalt $\chi^{2}$-testi, mittepaarisvalimi t-testi ja Manni-Whitney U-testiga. Küberkiusamiskäitumist defineerivate kriteeriumite ja liikide puhul ei tuvastatud poiste ja tüdrukute hinnangute vahel ühtegi statistiliselt olulist erinevust. Seevastu küberkiusamise kriteeriumite ja liikide tõsidust tajusid poisid ja tüdrukud erinevalt.
\end{abstract}

Võtmesõnad: küberkiusamise kriteeriumid, küberkiusamise liigid, taju, soolised erinevused

\section{Sissejuhatus}

Küberkiusamise kui uue kiusamisvormi teaduslik uurimine sai alguse kümmekond aastat tagasi (nt Li, 2006; Patchin \& Hinduja, 2006). Infoja kommunikatsioonitehnoloogia tormiline areng on hoidnud selle teema siiani pidevas muutumises ning aktuaalsena. Küberkiusamise uurimisel on keskendutud kiusajate ja ohvrite osakaalu väljaselgitamisele, tähelepanu

1 Haridusteaduste instituut, sotsiaal- ja haridusteaduskond, Tartu Ülikool, Salme 1a, 50103 Tartu; karin.naruskov@ut.ee 
on saanud küberkiusamise keskkonnad, vahendid ja liigid (nt Kowalski \& Limber, 2007; Patchin \& Hinduja, 2006; Slonje \& Smith, 2008; Smith et al., 2008). Vaadeldud on ka soolisi erinevusi (nt Ang \& Goh, 2010; Beckman, Hagquist, \& Hellström, 2013; Connell, Schell-Busey, Pearce, \& Negro, 2014; Li, 2006; Smith et al., 2008). Viimastel aastatel on aktuaalseks muutunud küberkiusamise mõõtmise ja defineerimise temaatika (nt Berne et al., 2013; Gradinger, Strohmeier, \& Spiel, 2010; Langos, 2012; Menesini et al., 2012; Menesini \& Nocentini, 2009; Naruskov, Luik, Nocentini, \& Menesini, 2012; Pieschl, Porsch, Kahl, \& Klockenbusch, 2013). Tavakiusamise uurimisel on tõstatatud küsimus, kas uurijad ja uuritavad tajuvad ning defineerivad kiusamist sarnaselt (Vaillancourt et al., 2008). Sama küsimuse võib esitada ka küberkiusamise kontekstis. Mitmed uurijad (nt Hinduja \& Patchin, 2008; Smith et al., 2008) on küberkiusamise mõiste defineerimisel lähtunud Olweuse (1999) tavakiusamise kriteeriumitest ning lisanud sellele elektroonilise keskkonna mõõtme. Märkida tuleb aga seda, et tegemist on teadlastest täiskasvanute definitsiooniga, mis ei pruugi kokku langeda õpilaste arusaamadega. Fenomeni sügavama mõistmise (sh mõõtmise) seisukohalt on oluline teada, kuidas õpilased ise küberkiusamise fenomeni tajuvad. Just Eesti õpilaste arusaamade uurimine selles kontekstis on vajalik, kuna meie õpilased on Euroopas ühed aktiivsemad ning samas ka riskialtimad internetikasutajad, kes on võrreldes teiste Euroopa riikide lastega kogenud peaaegu kaks korda rohkem küberkiusamist (Haddon \& Livingstone, 2012). Mitmed küberkiusamise uurijad on küberkiusamise fenomeni tajumise temaatikale küll tähelepanu pööranud (nt Grigg, 2010; Mishna, Saini, \& Solomon, 2009; Naruskov et al., 2012; Vandebosch \& Van Cleemput, 2008), kuid just soolised erinevused on need, mida on jõutud veel vähe uurida, mistõttu ei ole teada, kuivõrd sarnaselt või erinevalt poisid ja tüdrukud küberkiusamise fenomeni tajuvad. Kuna küberkiusamise kontekstis on soolise võrdluse uuringute tulemused üsna vastuolulised, siis võib küberkiusamise fenomeni tajumise uurimine just soolisest aspektist teemasse selgust tuua.

\section{Küberkiusamise definitsioon ja kriteeriumid}

Olweuse (2011) järgi on kiusamine pahatahtlik ja korduv rünnak inimese vastu, kellel on füüsiliselt või vaimselt raske end kiusaja eest kaitsta. Olweuse $(1999,2011)$ definitsioonist ilmnevad kolm kiusamise kriteeriumit:

a) tahtlikkus - kiusaja soovib oma tegevusega ohvrile füüsilist või psühholoogilist kahju tekitada;

b) korduvus - kiusaja peab tegutsema korduvalt ning pikema ajavahemiku vältel, kiusamiseks ei saa nimetada ühekordset mittetõsist tegu; 
c) tasakaalutus võimusuhetes - kiusaja ja ohvri võimusuhetes peab valitsema vaimne ja/või füüsiline tasakaalutus, kiusamiseks ei saa nimetada konflikti kahe füüsiliselt ja vaimselt võrdse osalise vahel.

Mitmed küberkiusamise uurijad on küberkiusamise defineerimisel osaliselt või täielikult lähtunud kolmest tavakiusamise kriteeriumist, lisades neile küberkeskkonna mõõtme (nt Hinduja \& Patchin, 2008; Smith et al., 2008). Smithi ja teiste (2008) järgi on küberkiusamine rühma või indiviidi tahtlik ja korduv agressiivne käitumine elektroonilisi suhtlusvahendeid kasutades, seejuures on ohvril raske ennast rünnakute eest kaitsta. Hinduja ja Patchini (2008) jaoks on küberkiusamine tahtlik ja korduv kahju tekitav käitumine arvutite, telefonide ja teiste elektrooniliste seadmete vahendusel.

Küberkiusamise defineerimisel on tõstatatud küsimus, kas ja kuivõrd puhtal kujul need kolm tavakiusamise kriteeriumit küberkeskkonnas toimuva kiusamise puhul avalduvad (Dooley, Pyżalsky, \& Cross, 2009; Kowalski, Limber, \& Agatston, 2008; Langos, 2012; Menesini \& Nocentini, 2009; Shariff, 2008; Slonje \& Smith, 2008). Peale selle on välja pakutud, et küberkiusamisel võivad olla küberkeskkonna spetsiifilisest olemusest tulenevad tunnused, täpsemalt on seejuures räägitud avalikkusest (vastandatult privaatsusele) ja anonü̈̈msusest (Menesini et al., 2012; Menesini \& Nocentini, 2009; Slonje \& Smith, 2008). Kübermaailmas toimuv suhtlus ning sellest tulenev kiusamine on väga avalik, sest toimuvale võivad tunnistajateks olla miljonid internetikasutajad üle maailma (Kowalski \& Limber, 2007). Näiteks on sotsiaalvõrgustikku postitatud pilte ja videoid võimalik näha ning edasi jagada väga suurel hulgal inimestel (Nocentini et al., 2010). Slonje ja Smithi (2008) uuringus osalenud 360 Rootsi õpilast vanusevahemikus 12-20 eluaastat hindasid teiste vahendite hulgas just piltide ja videote vahendusel toimuva kiusamise mõju ohvrile tõsisemaks kui tavakiusamise oma. Õpilased põhjendasid, et pildid ja videod on kübermaailmas väga avalikud ning suurele hulgale inimestele kättesaadavad (Slonje \& Smith, 2008).

Samas on kübermaailm oma olemuselt anonüümne: info- ja kommunikatsioonitehnoloogiat kasutades tajuvad inimesed end anonüümsetena või saavad väga lihtsate vahendite (nt libakontode) abil endas anonüümsustunde tekitada ning sellega veel rohkem ohvrit hirmutada (Kowalski et al., 2008; Kowalski \& Limber, 2007; Shariff, 2008; Willard, 2007). Vandeboschi ja Cleemputi (2008) korraldatud fookusrühma intervjuudest 279 õpilasega vanusevahemikus 10-18 eluaastat selgus, et just kiusaja anonüümsus on see, mis võib panna ohvrit tundma end jõuetu ja kaitsetuna. Kowalski ja Limber (2007) kirjutavad samuti, et ohvri jaoks on vaenlane, keda tuntakse, 
vähem hirmutav vaenlasest, kelle isik jääb ohvrile varjatuks. Kübermaailma anonüümne iseloom võimaldab inimesel oma vastutustundetut ja pahatahtlikku käitumist lihtsamalt ratsionaliseerida, kuna tuntakse end tabamatuna ning sageli puudub küberkeskkonnas otsene hukkamõist või reaalne karistusoht (Willard, 2007). Lisaks ei saa inimesed kübermaailma anonüümse iseloomu tõttu oma pahatahtlikule käitumisele adekvaatset tagasisidet, kuna ohver tundub nähtamatu, mistõttu on häiritud ka inimeste empaatiavõime (Kowalski \& Limber, 2007; Willard, 2007).

Varem on viit küberkiusamise kriteeriumit sügavuti käsitletud Naruskovi jt (2012), Nocentini jt (2010) ja Menesini jt (2012) uurimuses, kus vaadeldi järgmiseid kiusamisliike: kirjalik-verbaalne kiusamine, visuaalne kiusamine, privaatsuse rikkumine, ignoreerimine. Menesini jt (2012) uurimuses võeti vaatluse alla, millised küberkiusamise kriteeriumid ja liigid defineerivad õpilaste arvates küberkiusamiskäitumist kõige paremini. Kuue Euroopa riigi (Itaalia, Hispaania, Prantsusmaa, Saksamaa, Eesti ja Rootsi) 11-17aastaste õpilastega saadud tulemused näitasid, et defineerivateks kriteeriumiteks olid tasakaalutus võimusuhetes ning tahtlikkus kombineeritult anonüümsusega. Naruskovi jt (2012) Eestis tehtud uuringus olid nendeks kriteeriumiteks tasakaalutus võimusuhetes ja anonüümsus.

\section{Küberkiusamise liigid}

Kuna kübermaailm on pidevas ja kiires muutumises, siis pole uurijatel ühtset nimekirja küberkiusamise liikidest. Samas on uurijad püüdnud luua nii loetelusid kui ka laiemaid kategooriaid, mille alla saaks kübermaailmas toimuvat liigitada (nt Menesini et al., 2012; Nocentini et al., 2010; Willard, 2007). Kõige tuntum neist on Willardi (2007) käsitlus, kus eristatakse seitset liiki käitumist: sõimamine (flaming), ahistamine (harassment), kuulujuttude levitamine (mustamine) (denigration), privaatsuse rikkumine (impersonation), saladuste levitamine (outing, trickery), ignoreerimine (exclusion), küberjälitamine (cyberstalking). Nocentini jt (2010) lõid Willardile (2007) tuginedes ja rünnaku iseloomu aluseks võttes oma kategooriad: kirjalik-verbaalne kiusamine, visuaalne kiusamine, privaatsuse rikkumine, ignoreerimine. Nende küberkiusamise liikide olemust on kirjeldatud Nocentini jt (2010) ja Menesini jt (2012) uurimuses.

Kirjalik-verbaalse kiusamise alla on liigitatud juhtumid, kus kiusamiskäitumise puhul kasutatakse kirjalikke ja/või verbaalseid vahendeid (nt telefonikõned, tekstsõnumid, e-kirjad, blogid, kiirsuhtlusprogrammid) (Menesini et al., 2012; Nocentini et al., 2010). Juvoneni ja Grossi (2008) veebipõhisest uuringust, milles osales 1454 Ameerika Ühendriikides elavat 
õpilast vanusevahemikus 12-17 eluaastat, selgus, et elektroonilises suhtluses kasutavad õpilased kõige rohkem e-kirju ja kiirsuhtlusprogramme. Mitmed varasemad uuringud on näidanud, et kirjalik-verbaalne kiusamine on õpilaste seas levinud (Dehue, Bolman, \& Völlink, 2008; Kowalski \& Limber, 2007; Slonje \& Smith, 2008). Rootsis tehtud uuring näitas, et nii kiusaja kui ka ohvri perspektiivist lähtudes on kõige levinum e-kirjade vahendusel toimuv kiusamine (Slonje \& Smith, 2008). Dehue jt (2008) uuringu kohaselt, kus osales 1211 põhi- ja keskkooli õpilast, kiusati kõige rohkem kiirsuhtlusprogrammi MSN vahendusel. Sarnased tulemused ilmnesid ka Kowalski ja Limberi (2007) uuringust, mis tehti Ameerika Ühendriikides 6.-7. klassi õpilaste seas: kiirsuhtlusprogrammidele järgnesid jututubades ja e-kirjade vahendusel toimuv kiusamine, mida võib samuti liigitada kirjalik-verbaalse kiusamise alla.

Visuaalse kiusamise puhul kasutatakse kiusamiseks pilte ja videoid, mida postitatakse eri keskkondadesse, saadetakse ja jagatakse (Menesini et al., 2012; Nocentini et al., 2010). Slonje ja Smithi (2008) korraldatud uuring näitas, et paljud ohvrid olid kogenud piltide ja videoklippide vahendusel toimuvat kiusamist - see oli e-kirjade järel teisel kohal. Juvoneni ja Grossi (2008) uuringust ilmnes, et piinlike piltide jagamisega oli kokku puutunud $18 \%$ ohvritest. Smithi jt (2008) ning Slonje ja Smithi (2008) uuringus paluti õpilastel hinnata küber- ja tavakiusamise mõju ohvrile. Mõlemal juhul hindasid õpilased piltide ja videoklippide vahendusel toimuva kiusamise mõju ohvrile tõsisemaks kui tavakiusamise oma. Slonje ja Smith (2008) põhjendavad tulemusi sellega, et pildid/videoklipid olid uuritud vahenditest kõige avalikuma suunitlusega ning nende abil saab ohvri äärmiselt ebamugavasse olukorda panna. Pieschl ja tema kolleegid (2013) leidsid analoogselt, et küberkiusamise ohvritel tekitas videote vahendusel toimuv kiusamine rohkem stressi ja negatiivseid tundeid (viha) kui tekstil põhinev kiusamine, lisaks sundis see ohvreid rakendama aktiivsemaid toimetulekustrateegiaid. Ka Nocentini jt (2010) kvalitatiivses uuringus lasti 70-1 Itaalia, Saksamaa ja Hispaania õpilasel hinnata eri kiusamisliikide tõsidust. Uuringus osalenud riikide õpilased pidasid visuaalset kiusamist teiste kiusamisliikidega võrreldes kõige tõsisemaks. Samas ilmnesid ka mõned kultuurilised eripärad. Nimelt tundus Itaalia õpilastele visuaalse kiusamise kõrval tõsisena ka kirjalik-verbaalne kiusamine, Hispaania ja Saksamaa õpilastele aga privaatsuse rikkumine (Nocentini et al., 2010).

Privaatsuse rikkumisega on tegemist juhtudel, kui kiusaja saab ligipääsu ohvri paroolile, kontole või privaatsele infole ning kasutab seda ära eesmärgiga panna ohver ebamugavasse olukorda (nt personaalse info avaldamine) (Menesini et al., 2012; Nocentini et al., 2010). Juvoneni ja Grossi (2008) 
kohaselt oli salasõnade vargusega kokku puutunud 33\% ning privaatsuse rikkumisega $25 \%$ ohvritest.

Ignoreerimise puhul on olulisel kohal rühmasuhted, täpsemalt see, kes kuulub rühma ja kes mitte, ning ignoreerimine leiabki aset siis, kui pahatahtlikel eesmärkidel ei võeta mõnda inimest näiteks sõbralistidesse või küberkeskkonnas toimuvatesse mängudesse (Menesini et al., 2012; Nocentini et al., 2010). Patchini ja Hinduja (2006) uuringu kohaselt oli ignoreerimist kogenud 60,4\% ohvritest. Dehue jt (2008) uuringust ilmnes, et ignoreerimist kui kiusamist oli rakendanud peaaegu 5\% kiusajatest, ohvrite puhul polnud seda kiusamisliiki üldse nimetatud. Nii Naruskovi jt (2012) kui ka Menesini jt (2012) uurimistulemused näitasid ühtmoodi (ainult üksikute eranditega), et õpilased pidasid ignoreerimist statistiliselt oluliselt vähem küberkiusamiseks võrreldes teiste vaadeldud küberkiusamise liikidega (kirjalik-verbaalne kiusamine, visuaalne kiusamine ja privaatsuse rikkumine). Naruskovi jt (2012) uurimistulemuste kohaselt peeti ignoreerimist pigem toimetulekustrateegiaks, mis võimaldab vältida ohvriks sattumist või teha lõppu kiusamisele.

\section{Soolised sarnasused ja erinevused küberkiusamisel}

Kui paljud tavakiusamise uuringud on näidanud, et poisid on kiusamiskäitumisega rohkem seotud kui tüdrukud (nt Kumpulainen, Räsänen, \& Henttonen, 1999; Seals \& Young, 2003), siis küberkiusamise kontekstis pole nii selget mustrit välja joonistunud. Dehue jt (2008) uuring näitas, et poisid olid statistiliselt oluliselt sagedamini küberkiusajateks võrreldes tüdrukutega ning tüdrukud statistiliselt oluliselt sagedamini küberohvriteks võrreldes poistega. Ka Li (2006) uuringu kohaselt olid poisid samamoodi statistiliselt oluliselt sagedamini küberkiusajad võrreldes tüdrukutega. Tüdrukute puhul langevad Dehue jt (2008) tulemused kokku Meschi (2009) ning Smithi jt (2008) omadega: mõlemal juhul olid tüdrukud statistiliselt oluliselt sagedamini kogenud küberkiusamist võrreldes poistega. Beckmani jt (2013) ning Kowalski ja Limberi (2007) uuringust ilmneb, et tüdrukud olid statistiliselt oluliselt sagedamini küberkiusajad ja küberkiusajad/küberohvrid kui poisid. Sarnase tulemuseni jõudsid ka Connell jt (2014): tüdrukud olid statistiliselt oluliselt sagedamini küberkiusajad ja ka küberkiusamise ohvrid võrreldes poistega. Mainimata ei saa jätta ka uuringuid, kus erinevalt eelmistest pole tüdrukute ja poiste vahel erinevusi tuvastatud - poisid pole olnud küberkiusamiskäitumisega statistiliselt oluliselt rohkem seotud kui tüdrukud ja vastupidi (Hinduja \& Patchin, 2008; Patchin \& Hinduja, 2006; Smith et al., 2008). 
Uurimistulemusi, mis näitavad, et tüdrukud on küberkiusamisega rohkem seotud kui poisid, on uurijad (Hinduja \& Patchin, 2009; Slonje \& Smith, 2008; Snell \& Englander, 2010; Willard, 2007) püüdnud põhjendada tavakiusamise uuringutega, mis on näidanud, et poisid on kiusajatena rohkem seotud otseste kiusamisvormidega (nt füüsiline kiusamine) ning tüdrukud rohkem kaudsete kiusamisvormidega (nt kuulujuttude levitamine, tagarääkimine) (Nansel et al., 2001). Kuna küberkiusamise võib liigitada pigem kaudseks kiusamiseks, siis on üsna loogiline, et kübermaailmas toimuva kiusamise puhul on sooline kaalukauss võrdne (Hinduja \& Patchin, 2009) või kaldub see pigem tüdrukute poole (Slonje \& Smith, 2008; Willard, 2007). Kuna küberkiusamine on sageli tekstipõhine, siis leiavad Hinduja ja Patchin (2009), et see on omasem tüdrukutele, erinevalt poistest, kes kipuvad oma väljendusviisilt olema pigem füüsilised. Ybarra ja Mitchell (2004) leiavad internetis toimuva ahistamise kontekstis, et tavaelus üldjuhul kuulekalt käituvad tüdrukud tunnevad end anonüümses kübermaailmas vähem pärsituna ning panevad ennast seal rohkem maksma.

Slonje ja Smithi (2008) uurimuse kohaselt on tüdrukud statistiliselt oluliselt rohkem kogenud e-kirjade vahendusel toimuvat kiusamist, poisid olid aga tekstsõnumite vahendusel toimuva kiusamise korral olnud ise statistiliselt oluliselt sagedamini kiusaja rollis. Teiste vaadeldud vahendite (telefonikõnede, piltide/videote) puhul statistilist erinevust ei tuvastatud. Ehk peituvad küberkiusamise erineva kogemise põhjused selles, et tüdrukute ja poiste tegevused internetis on erinevad, kuid varasemate uurimuste põhjal pole siin selget reeglipärasust esile tulnud. Juvoneni ja Grossi (2008) tehtud uuringust selgus, et poistega võrreldes kasutavad tüdrukud statistiliselt oluliselt sagedamini e-kirju, lehekülgi, kus saab endale profiili luua (profile sites), blogisid ja mobiiltelefone. Grossi, Juvoneni ja Gable'i (2002) uuringus, kus osales 130 California osariigi 7. klassi õpilast, poiste ja tüdrukute internetikasutuses statistiliselt olulisi erinevusi ei leitud. Beckmani jt (2013) uuring, kus osalesid 2989 Rootsi õpilast vanusevahemikus 13-15 eluaastat, näitas, et küberkiusamisel avalduvad soolised erinevused ei saa tuleneda ka erinevast juurdepääsust mobiiltelefonidele, arvutitele ja internetile, kuna poisid ja tüdrukud olid selle poolest võrdsed.

Tüdrukute ja poiste erinevusi küberkiusamise kogemisel on püütud seletada ka laiemalt sotsialiseerimise ning ühiskonna pealesurutud soorollidega. Rootsis $10-12$ aastaste õpilaste seas $(n=694)$ korraldatud uuringus vaadeldi, mis toimetulekustrateegiaid õpilased küberkiusamise ohvriks sattununa kasutaksid, seejuures keskenduti vanusest ja soost tulenevatele erinevustele (Frisén, Berne, \& Marin, 2014). Rootslaste uurimistulemused näitasid, et erinevalt poistest rääkisid tüdrukud toimunud 
küberkiusamisest statistiliselt oluliselt sagedamini lapsevanemale, õpetajale ja sõbrale. Sarnased tulemused ilmnesid ka Li (2006) uuringust. Rootsi poisid nägid tüdrukutega võrreldes kättemaksu tavaelus statistiliselt oluliselt sagedamini toimetulekustrateegiana (Frisén et al., 2014). Frisén jt (2014) viitavad tulemusi põhjendades sotsialiseerimise käigus poiste ja tüdrukute omaks võetud traditsioonilistele soorollidele, mille kohaselt on tüdrukud „tunnetest ja mõtetest rääkijad” ning poisid keerulistes situatsioonides „vägivalla kasutajad”. Kuigi Rootsi on soolise võrdõiguslikkuse poolest üks maailma juhtriike, leiavad Frisén jt (2014) oma uurimistöö tulemustele toetudes, et traditsioonilised soorollid tunduvad olevat sellest hoolimata visad kaduma. Shariff (2008) leiab samuti, et need soorollid, mida on lapsevanemad, meedia ja laiemalt kogu ühiskond lastele peale surunud, võivad avalduda küberkeskkonnas. Selle seisukoha illustreerimiseks toob Shariff (2008) näite, kuidas meedia on loonud kuvandi tüdrukutest kui habrastest ja ebakompetentsetest tehnoloogiliste vahendite kasutajatest, kes on kergesti haavatavad ning kes seetõttu vajavad kaitset küberkiusajate eest, samal ajal kui poisse kujutletakse agressiivsematena ja tõenäoliste küberkiusajatena. Beckman jt (2013) analüüsivad teemat teisest vaatenurgast ning leiavad, et nii interneti kasutamine kui ka küberkiusamine on tavakiusamise kõrval suhteliselt uued nähtused, mis pole jõudnud nii tugevasti ühiskonda sisse juurduda. Uurijad oletavad, et just küberkeskkonnas võib olla lihtsam soorollidega etteseatud piire murda (Beckman et al., 2013).

Eeltoodust ilmneb, et põhjusi, miks poisid ja tüdrukud kogevad küberkiusamist erineval määral, on otsitud tavakiusamise teooriast (Hinduja \& Patchin, 2009; Slonje \& Smith, 2008; Snell \& Englander, 2010; Willard, 2007), vaadeldud on laiemalt poiste ja tüdrukute internetikasutust (Beckman et al., 2013) ning analüüsitud ühiskonna, meedia, sotsialiseerimise ja soorollide mõju (Beckman et al., 2013; Frisén et al., 2014; Shariff, 2008).

\section{Eesmärk ja uurimisküsimused}

Tavakiusamise puhul on oletatud, et poisid ja tüdrukud võivad kiusamist ning sellega seonduvat erinevalt tajuda (Smith et al., 2002). Smithi jt (2002) uurimistulemused seda oletust aga ei kinnitanud. Kuigi Smithi jt (2002) uuringus poiste ja tüdrukute vahel fenomeni tajumises erinevust ei leitud, väärib teema siiski käsitlemist ka küberkiusamise kontekstis. Seetõttu on praeguse uurimuse eesmärk võrrelda poiste ja tüdrukute vahelisi erinevusi küberkiusamise fenomeni tajumisel, lähtudes kiusamise kriteeriumitest (tahtlikkus, korduvus, tasakaalutus võimusuhetes, avalikkus/privaatsus, 
anonü̈̈msus) ja liikidest (kirjalik-verbaalne kiusamine, visuaalne kiusamine, privaatsuse rikkumine, ignoreerimine). Uurimuses otsitakse vastuseid küsimusele, millised on poiste ja tüdrukute vahelised erinevused küberkiusamise fenomeni tajumisel küberkiusamise kriteeriumite ja liikide puhul.

\section{Meetod}

\section{Valim}

Uuringus osales 336 Eesti õpilast vanuses 11-17 eluaastat (keskmine vanus 14,04; standardhälve 1,46). Valimi moodustamisel jälgiti, et poisid ja tüdrukud ning noorem ja vanem vanuseaste oleks valimis esindatud võrdselt. Ankeedi täitnutest 163 olid tüdrukud ja 173 poisid. Õpilaste sooline, vanuseline ja klassiline jaotus on esitatud tabelis 1 .

Valimis oli kuus põhikooli ja kuus keskkooli, vastavalt 118 ja 218 õpilast. Koolide valikul peeti silmas, et valimisse kuuluksid nii suurlinna $(N=6)$, väikelinna $(N=3)$ kui ka maapiirkonna koolid $(N=6)$. Koolide valik nendes rühmades tehti mugavusvalimi alusel. Valimisse võeti koolid, kus uuringu läbiviijatel olid juba kontaktid olemas või kellelt saadi kõige kiiremini nõusolek uuringus osaleda. Linnakoolides ja suuremates väikelinnakoolides, kus klassides õppis rohkem õpilasi, valiti ankeeti täitma klassi nimekirjast iga kolmas poiss ja iga kolmas tüdruk. Lugemist alustati klassi nimekirjas K-tähest. Maakoolides ja väiksemates väikelinnakoolides anketeeriti kõiki sellel päeval koolis olnud õpilasi.

Tabel 1. Uuringus osalejate sooline, vanuseline ja klassiline jaotus

\begin{tabular}{|c|c|c|}
\hline & $\begin{array}{l}\text { Poisid } \\
(N=173 ; 52 \%)\end{array}$ & $\begin{array}{l}\text { Tüdrukud } \\
(N=163 ; 48 \%)\end{array}$ \\
\hline $\begin{array}{l}\text { Keskmine vanus ja } \\
\text { standardhälve }\end{array}$ & 14,06 (standardhälve 1,45 ) & 14,02 (standardhälve 1,49) \\
\hline Klass & $\begin{array}{l}\text { 5. klass }-26 \%(N=46) \\
6 . \text { klass }-21 \%(N=36) \\
\text { 7. klass }-4 \%(N=7) \\
8 . \text { klass }-36 \%(N=62) \\
9 . \text { klass }-13 \%(N=22)\end{array}$ & $\begin{array}{l}\text { 5. klass }-30 \%(N=49) \\
6 . \text { klass }-20 \%(N=32) \\
\text { 7. klass }-2 \%(N=3) \\
\text { 8. klass - } 36 \%(N=59) \\
\text { 9. klass }-12 \%(N=20)\end{array}$ \\
\hline Kokku & $100 \%(N=173)$ & $100 \%(N=163)$ \\
\hline
\end{tabular}




\section{Mõõtevahend}

Mõõtevahendina kasutati Euroopa projekti COST Action IS0801 raames valminud ankeeti. Anketeerimisele eelnes fookusrühma intervjuu, mille käigus katsetati ankeedis kasutatavate stsenaariumite sobivust ja arusaadavust õpilastele, sh selgitati välja termin, mis õpilaste arvates kirjeldas kõige paremini stsenaariumites esitatud küberkiusamise situatsioone. Fookusrühma intervjuude analüüsi tulemusena selgus, et termin küberkiusamine oli õpilaste jaoks võõras ning nad kasutavad küberkiusamisest rääkides terminit kiusamine. Fookusrühma intervjuu tulemusi võeti arvesse ankeedi koostamisel, seejuures kasutati ankeedis terminit kiusamine. Fookusrühma intervjuu tulemusi on kajastatud Naruskovi jt (2012) uurimuses. Ankeet koostati COST Action IS0801 tegevuse raames ingliskeelsena, seejärel tõlgiti see uuringus osalenud riikide keelde, sh eesti keelde, ning ekvivalentsuse eesmärgil tehti tagasitõlge inglise keelde. Ankeedi valiidsusele andsid hinnangu COST Action IS0801 tegevuses osalenud küberkiusamise uurimise eksperdid. Ankeedi adapteerimisel Eesti kultuurikonteksti arvestati Beatoni, Bombardieri, Guillemini ja Ferrazi (2000) soovitusi. Ankeedi sobivust katsetati ning ankeet kohandati siinsele kultuurikontekstile. Mõõtevahendi alguses anti õpilastele ülevaade uuritavast teemast ja ankeedi ülesehitusest ning juhised ankeedi täitmiseks. Lisaks seletati lahti kaks mõistet, mis stsenaariumites esinesid: privaatne info ja sõbralist. Ankeedi algusesse olid paigutatud küsimused õpilase taustandmete kohta (sünniaasta, klass, konkreetses koolis õpitud aastad, sugu), nendele järgnesid 32 stsenaariumit koos õpilastele suunatud küsimustega.

Stsenaariumites kirjeldati ankeedi täitjale, mis on kiusaja ja ohvri vahel toimunud: kuidas kiusaja tegutses, millised olid tema kavatsused, kuidas ohver reageeris. Ohvrit märgiti stsenaariumites tähega $\mathrm{C}$ ning kiusajat tähega $M$. Õpilastele rõhutati, et $C$ ja $M$ võivad olla nii poisid kui ka tüdrukud. Oppilane pidi iga stsenaariumi puhul hindama, kas tema arvates on tegemist kiusamisega või mitte (skaala „ei/jah”). Kui stsenaarium hinnati kiusamiseks, siis paluti ankeedi täitjal neljapallilisel skaalal („mitte eriti tõsine”, „küllaltki tõsine”, „tõsine”, „väga tõsine”) hinnata, kui tõsiseks ta seda ohvri jaoks peab. Järgnevalt on esitatud ühe stsenaariumi näide.

M. saatis solvava tekstsõnumi oma tuttavale poisile/tüdrukule C-le.

M. tegi seda vaid üks kord ja mõtles seda naljana, kuid C. läks selle peale endast välja ja ei teadnud, kuidas end kaitsta. Kas see on kiusamine? Kui jah, siis kui tõsine see on? 
Stsenaariumite koostamise aluseks olid viis küberkiusamise kriteeriumit ja neli liiki (Nocentini et al., 2010). Iga küberkiusamise liigi (kirjalik-verbaalne kiusamine, visuaalne kiusamine, privaatsuse rikkumine, ignoreerimine) kohta koostati 32 stsenaariumit, milles oli erinevalt kombineeritud viit küberkiusamise kriteeriumit (tahtlikkus, korduvus, tasakaalutus võimusuhetes, avalikkus/privaatsus, anonüümsus), kokku seega 128 stsenaariumit (vt tabel 2 ja lisa 1). Kõigi viie kriteeriumi puhul pooltes stsenaariumites (16) kriteerium esines ning pooltes (16) kriteerium puudus (vt lisa 1).

Tabel 2. Küberkiusamise kriteeriumid ja liigid stsenaariumites

\begin{tabular}{|c|c|c|c|}
\hline $\begin{array}{l}\text { Küberkiusamise } \\
\text { kriteerium }\end{array}$ & $\begin{array}{l}\text { Kriteeriumi esinemise ja } \\
\text { puudumise näide }\end{array}$ & $\begin{array}{l}\text { Küberkiusamise } \\
\text { liik }\end{array}$ & Näide \\
\hline Tahtlikkus & $\begin{array}{l}\text { "tahtes sellega C-le tahtlikult } \\
\text { haiget teha” vs. „M. mõtles } \\
\text { seda naljana” }\end{array}$ & $\begin{array}{l}\text { Kirjalik- } \\
\text { verbaalne } \\
\text { kiusamine }\end{array}$ & $\begin{array}{l}\text { „M. saatis solvava } \\
\text { tekstsõnumi” }\end{array}$ \\
\hline $\begin{array}{l}\text { Tasakaalutus } \\
\text { võimusuhetes }\end{array}$ & $\begin{array}{l}\text { "C. läks endast välja ja ei tead- } \\
\text { nud, kuidas end kaitsta" vs. } \\
\text { „C. ei teinud sellest välja” }\end{array}$ & $\begin{array}{l}\text { Visuaalne } \\
\text { kiusamine }\end{array}$ & $\begin{array}{l}\text { "M. saatis C-le } \\
\text { piinliku sisuga } \\
\text { foto" }\end{array}$ \\
\hline Korduvus & $\begin{array}{l}\text { „viimase kuu jooksul } \\
\text { korduvalt" vs. „üks kord” }\end{array}$ & Ignoreerimine & $\begin{array}{l}\text { „M. kustutas oma } \\
\text { tuttava poisi/ } \\
\text { tüdruku C. oma } \\
\text { sõbralistist" }\end{array}$ \\
\hline $\begin{array}{l}\text { Avalikkus/ } \\
\text { privaatsus }\end{array}$ & $\begin{array}{l}\text { „M. saatis teistele inimestele } \\
\text { vaatamiseks/lugemiseks" vs. } \\
\text { „M. saatis ainult C-le" }\end{array}$ & $\begin{array}{l}\text { Privaatsuse rik- } \\
\text { kumine }\end{array}$ & $\begin{array}{l}\text { „M. sai ligipääsu } \\
\text { C. paroolile või } \\
\text { privaatsele infole” }\end{array}$ \\
\hline Anonüümsus & $\begin{array}{l}\text { "C. ei tundnud M-i isiklikult" } \\
\text { vs. „tuttavale poisile/tüdrukule } \\
\text { C-le" }\end{array}$ & & \\
\hline
\end{tabular}

Märkused. Algallikad: Naruskov jt (2012) ja Menesini jt (2012). C - ohver; M - kiusaja.

Kuna 128 stsenaariumi hindamine olnuks liiga ajamahukas ning õpilaste jaoks üle jõu käiv, siis loodi nende põhjal neli küsimustiku versiooni, mis jagati võrdsetes proportsioonides õpilaste (sh sugude ja vanuseklasside) vahel ära. Iga õpilane pidi andma hinnangu 32 stsenaariumile, mis jagunesid nelja küberkiusamise liigi vahel (vt tabel 3). 
Tabel 3. Küberkiusamise liikide kombineerimine küsimustiku neljas versioonis

\begin{tabular}{c|c|c|c|c}
\hline \multirow{2}{*}{$\begin{array}{c}\text { Küsimustiku } \\
\text { versioon }\end{array}$} & \multicolumn{4}{|c}{ Stsenaariumid } \\
\cline { 2 - 5 } & $\mathbf{1 - 8}$ & $\mathbf{9 - 1 6}$ & $\mathbf{1 7 - 2 4}$ & $\mathbf{2 5 - 3 2}$ \\
\hline VERSIOON 1 & $\mathrm{KV}$ & $\mathrm{I}$ & $\mathrm{P}$ & $\mathrm{V}$ \\
\hline VERSIOON 2 & $\mathrm{I}$ & $\mathrm{V}$ & $\mathrm{KV}$ & $\mathrm{P}$ \\
\hline VERSIOON 3 & $\mathrm{V}$ & $\mathrm{P}$ & $\mathrm{I}$ & $\mathrm{KV}$ \\
\hline VERSIOON 4 & $\mathrm{P}$ & $\mathrm{KV}$ & $\mathrm{V}$ & $\mathrm{I}$ \\
\hline
\end{tabular}

Märkus. KV - kirjalik/verbaalne; I - ignoreerimine; $\mathrm{P}$ - privaatsuse rikkumine; $\mathrm{V}$ - visuaalne.

\section{Protseduur}

Ajavahemikul veebruar-mai 2011 koguti andmed 12 Eesti põhi- ja keskkoolis. Anketeerimine toimus koolipäeval ning lapsevanemad olid sellest teadlikud. Õpetajad teavitasid õpilasi, et küsimustiku täitmine on vabatahtlik ja anonüümne ning saadud andmeid kasutatakse ainult uurimistöö eesmärgil. Uurijad instrueerisid õpetajaid, kuidas küsimustikku hallata ja vajaduse korral õpilasi juhendada. Küsimustiku täitmine võttis aega 15-20 minutit.

Andmeid analüüsiti eraldi küberkiusamise kriteeriumite ja liikide kaupa. Kriteeriumite puhul võeti esmalt vaatluse alla eraldi stsenaariumid 1-32 (vt lisa 1) ning $\chi^{2}$-testiga võrreldi poiste ja tüdrukute vastuseid küsimusele „Kas see on kiusamine?”. Kõigi 32 stsenaariumi puhul võrreldi ka poiste ja tüdrukute hinnanguid stsenaariumite tõsidusele. Selleks kasutati Manni-Whitney U-testi. Teiseks leiti küsimuse „Kas see on kiusamine?” puhul iga osaleja hinnangute koondnäitajad (protsent) kriteeriumite lõikes. Täpsemalt arvutati iga kriteeriumi puhul kokku protsent stsenaariumitest, kus kriteerium esines (vt tabel 2 ja lisa 1). Näiteks tuli küberkiusamise kriteeriumi korduvus koondnäitajaks 100\% siis, kui õpilane oli hinnanud küberkiusamiseks kõik stsenaariumid, kus korduvus esines. Saadud protsentjaotusi võrreldi poiste ja tüdrukute vaheliste erinevuste väljaselgitamiseks mittepaarisvalimi t-testiga. Niisamuti vaadeldi õpilaste hinnanguid küberkiusamise kriteeriumite tõsidusele. Kuna hinnangud olid esitatud neljapallilisel skaalal, siis arvutati koondnäitajaks mediaan. Täpsemalt arvutati iga kriteeriumi puhul kokku mediaan stsenaariumitest, kus kriteerium esines (vt tabel 2 ja lisa 1). Poiste ja tüdrukute hinnanguid küberkiusamise kriteeriumite lõikes võrreldi ja nende statistilist olulisust kontrolliti Manni-Whitney U-testiga. 
Küberkiusamise liikide analüüsimisel toimiti samamoodi nagu küberkiusamise kriteeriumite puhul. Arvutati küsimuse „Kas see on kiusamine?” koondnäitaja (protsent), kuid siin tehti seda eraldi iga nelja küberkiusamise liigi (kirjalik-verbaalne, visuaalne, privaatsuse rikkumine, ignoreerimine) kohta. Saadud protsentjaotusi võrreldi poiste ja tüdrukute vaheliste erinevuste väljaselgitamiseks mittepaarisvalimi t-testiga. Ka küberkiusamise liikide lõikes võrreldi poiste ja tüdrukute hinnanguid tõsidusele. Selleks arvutati iga liigi kohta eraldi koondnäitajaks mediaan. Poiste ja tüdrukute hinnanguid küberkiusamise tõsidusele liikide kaupa võrreldi ManniWhitney U-testiga.

\section{Tulemused}

\section{Poiste ja tüdrukute võrdlus stsenaariumite alusel}

Jooniselt 1 on stsenaariumite kaupa näha, kui palju poisse ja tüdrukuid vastas küsimusele „Kas see on kiusamine?” jaatavalt. Stsenaariumite all peetakse silmas lisas 1 esitatud stsenaariumeid 1-32, millest igaühes on viit küberkiusamise stsenaariumit erinevalt kombineeritud. Stsenaariumite analüüsimine küberkiusamise liikide kaupa polnud võimalik, kuna küsimustiku täitja ei hinnanud stsenaariumeid 1-32 ühe liigi lõikes, küsimustik oli kombineeritud neljast liigist (vt tabel 3).

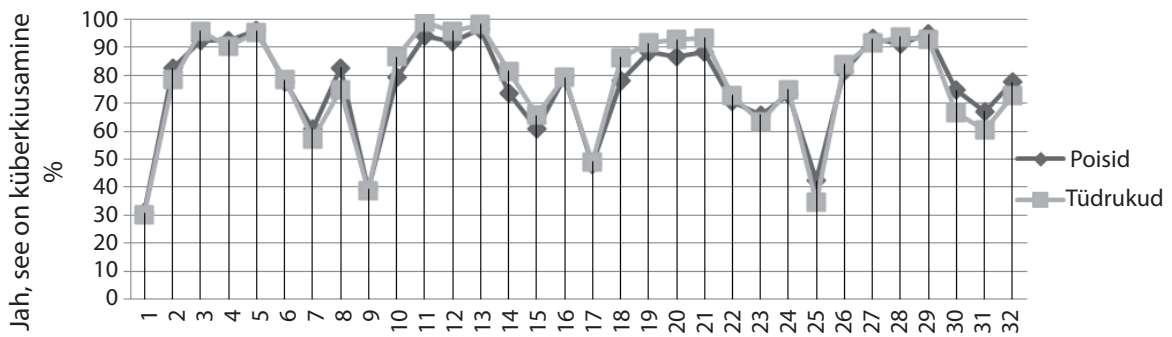

Stsenaariumid

Joonis 1. Poiste ja tüdrukute jaatavad vastused küsimusele „Kas see on kiusamine?" stsenaariumite kaupa $(* 0<05)$

Jooniselt 1 on näha, et poiste ja tüdrukute vastuste dünaamika on sarnane. Ka andmeanalüüs näitas, et poiste ja tüdrukute hinnangud olid statistiliselt oluliselt erinevad stsenaariumite 11 ja 18 puhul (vt lisa 1). Stsenaariumis 11 oli tegemist ühekordse juhtumiga, kus osalised tundsid üksteist (anonüümsuse puudumine), kiusaja tegutses tahtlikult haiget tegemise eesmärgil, kaasas sellesse kõrvalised isikud (avalikkus) ning eksisteeris tasakaalutus 
võimusuhetes. Stsenaariumis 18 oli tegemist ühekordse juhtumiga, kus kiusaja eesmärk polnud pahatahtlik (tahtlikkuse puudumine), toimunusse olid kaasatud kõrvalised isikud (avalikkus), eksisteeris tasakaalutus võimusuhetes ning ohvri jaoks jäi kiusaja anonü̈̈mseks. Stsenaariumeid 11 ja 18 hindasid tüdrukud sagedamini küberkiusamiseks kui poisid ja see erinevus oli statistiliselt oluline $(p<0,05)$. Ülejäänud stsenaariumite puhul soolisi erinevusi ei ilmnenud.

Andmeanalüüsi käigus võrreldi ka poiste ja tüdrukute hinnanguid stsenaariumite 1-32 tõsidusele. Tulemused on esitatud tabelis 4 .

Tabel 4. Poiste ja tüdrukute hinnangute võrdlus stsenaariumite 1-32 tõsiduse alusel

\begin{tabular}{|c|c|c|c|}
\hline Stsenaarium & z-statistik & Stsenaarium & z-statistik \\
\hline 1 & $-1,822$ & 17 & $-2,675^{* *}$ \\
\hline 2 & $-1,297$ & 18 & $-1,130$ \\
\hline 3 & $-0,603$ & 19 & $-0,875$ \\
\hline 4 & $-0,175$ & 20 & $-1,293$ \\
\hline 5 & $-0,819$ & 21 & $-0,256$ \\
\hline 6 & $-0,175$ & 22 & $-1,926$ \\
\hline 7 & $-1,163$ & 23 & $-2,415^{*}$ \\
\hline 8 & $-1,575$ & 24 & $-1,319$ \\
\hline 9 & $-3,159^{* *}$ & 25 & $-0,770$ \\
\hline 10 & $-0,218$ & 26 & $-0,360$ \\
\hline 11 & $-0,137$ & 27 & $-0,202$ \\
\hline 12 & $-0,641$ & 28 & $-2,265^{*}$ \\
\hline 13 & $-0,014$ & 29 & $-0,412$ \\
\hline 14 & $-2,002^{*}$ & 30 & $-1,507$ \\
\hline 15 & $-2,084^{*}$ & 31 & $-1,998^{*}$ \\
\hline 16 & $-2,778^{* *}$ & 32 & $-1,125$ \\
\hline
\end{tabular}

Märkus. ${ }^{*} p<0,05 ;{ }^{* *} p<0,01$.

Tabelist 4 on näha, et poiste ja tüdrukute hinnangud tõsidusele olid statistiliselt oluliselt erinevad stsenaariumite 9, 14, 15, 16, 17, 23, 28 ja 31 puhul. Poisid hindasid tüdrukutega võrreldes neid stsenaariumeid tõsisemaks ja see erinevus oli statistiliselt oluline $(p<0,05$ ja $p<0,01)$. Stsenaariumites 
9, 14, 15, 16, 17 ja 23 esines avalikkuse kriteerium ning puudus tasakaalutus võimusuhetes ohvri ja kiusaja vahel. Stsenaariumeid 28 ja 31 ühendas anonüümsuse ja korduvuse kriteeriumi olemasolu ning tahtlikkuse ja avalikkuse kriteeriumi puudumine (vt lisa 1).

\section{Poiste ja tüdrukute võrdlus küberkiusamise kriteeriumite alusel}

Statistilise analüüsi käigus vaadeldi, kas poisid ja tüdrukud tajuvad küberkiusamist erinevalt, lähtudes küberkiusamise kriteeriumitest. Tabelist 5 ilmneb, et küberkiusamise kriteeriumite poolest olid poiste ja tüdrukute hinnangud sarnased, ning ka andmeanalüüs kinnitas, et poiste ja tüdrukute vahel selles statistiliselt olulisi erinevusi polnud $(p>0,05)$. See tähendab, et poisid ei liigitanud küberkiusamise kriteeriumite olemasolust lähtudes stsenaariumeid oluliselt sagedamini küberkiusamiseks kui tüdrukud ja vastupidi (vt tabel 5).

Tabel 5. Poiste ja tüdrukute hinnangute võrdlus küberkiusamise kriteeriumite alusel

\begin{tabular}{l|c|c|c|c}
\hline Kriteerium & $\begin{array}{c}\text { Poiste } \\
\text { keskmine } \\
\%^{1}\end{array}$ & $\begin{array}{c}\text { Tüdrukute } \\
\text { keskmine } \\
\%^{1}\end{array}$ & t-statistik & $\boldsymbol{p}$-väärtus \\
\hline Tahtlikkus & 84 & 85 & $-0,160$ & 0,873 \\
\hline Korduvus & 81 & 81 & 0,182 & 0,856 \\
\hline Tasakaalutus võimusuhetes & 89 & 91 & $-1,673$ & 0,097 \\
\hline Avalikkus & 76 & 79 & $-1,614$ & 0,107 \\
\hline Anonüümsus & 76 & 76 & 0,151 & 0,880 \\
\hline
\end{tabular}

Märkus. ${ }^{1}$ - mitteparameetrilise $t$-testi väljastatud võrreldud rühmade keskmised, mis näitavad protsentides, kui paljud poistest ja tüdrukutest vastasid küsimusele „Kas see on kiusamine?" jaatavalt.

Tabelist 5 on näha, et poiste ja tüdrukute vastuste dünaamika oli kriteeriumite lõikes sarnane. Tähelepanu tuleb pöörata aga sellele, et kõigi liikide puhul küündib „Jah, see on kiusamine” vastanud õpilaste protsent $75 \mathrm{ni}$. Nii poisid kui ka tüdrukud olid kõige rohkem kiusamiseks nimetanud stsenaariumeid, milles esines kriteerium „tasakaalutus võimusuhetes”.

Analüüsides poiste ja tüdrukute hinnanguid küberkiusamise kriteeriumite tõsidusele, selgus, et poisid hindasid tõsisemaks stsenaariumeid, kus esines korduvuse (Manni-Whitney U-test; $z=-2,049 ; p<0,05$ ), avalikkuse (Manni-Whitney U-test; $z=-2,940 ; p<0,01)$ ja anonüümsuse kriteerium (Manni-Whitney U-test; $z=-3,082 ; p<0,01$ ) (vt tabel 6). 
Tabel 6. Poiste ja tüdrukute hinnangud stsenaariumite tõsidusele küberkiusamise kriteeriumite kaupa

\begin{tabular}{l|c|c|c|c}
\hline Kriteerium & $\begin{array}{c}\text { Poisid } \\
\%^{1}\end{array}$ & $\begin{array}{c}\text { Tüdrukud } \\
\%^{1}\end{array}$ & z-statistik & p-väärtus \\
\hline Tahtlikkus & 37 & 33 & $-1,038$ & 0,299 \\
\hline Korduvus & 43 & 32 & $-2,049$ & $0,040^{*}$ \\
\hline Tasakaalutus võimusuhetes & 48 & 44 & $-1,102$ & 0,270 \\
\hline Avalikkus & 32 & 22 & $-2,940$ & $0,003^{* *}$ \\
\hline Anonüümsus & 33 & 20 & $-3,082$ & $0,002^{* *}$ \\
\hline
\end{tabular}

Märkused. ${ }^{*} p<0,05 ;{ }^{* *} p<0,01 .{ }^{1}$ - protsent poistest ja tüdrukutest, kelle hinnangute koondmediaan oli neljapallilisel skaalal suurem kui 2,5 ehk kelle hinnanguid loeti tõsiseks.

Tabelist 6 on näha, et ka tõsiduse hinnangutes kerkis mõlema soo puhul esile kriteeriumi „tasakaalutus võimusuhetes” esinemine stsenaariumites: $48 \%$ poistest ja $44 \%$ tüdrukutest hindasid seda kriteeriumit sisaldanud stsenaariumid tõsiseks.

\section{Poiste ja tüdrukute võrdlus küberkiusamise liikide alusel}

Poiste ja tüdrukute võrdlemisel küberkiusamise liikide alusel ei näidanud küsimuse „Kas see on kiusamine?” korral statistiline analüüs ühtegi statistiliselt olulist erinevust $(p>0,05)$. See tähendab, et poisid ei nimetanud ühtegi neljast küberkiusamise liigist statistiliselt oluliselt sagedamini küberkiusamiseks kui tüdrukud ning vastupidi (vt tabel 7).

Tabel 7. Poiste ja tüdrukute hinnangute võrdlus küberkiusamise liikide alusel

\begin{tabular}{l|c|c|c|c}
\hline Küberkiusamise liik & $\begin{array}{c}\text { Poiste } \\
\text { keskmine } \\
\%^{1}\end{array}$ & $\begin{array}{c}\text { Tüdrukute } \\
\text { keskmine } \\
\%^{1}\end{array}$ & t-statistik & $p$-väärtus \\
\hline Kirjalik-verbaalne kiusamine & 80 & 81 & $-0,592$ & 0,554 \\
\hline Privaatsuse rikkumine & 83 & 83 & $-0,189$ & 0,851 \\
\hline Visuaalne kiusamine & 83 & 85 & $-0,870$ & 0,385 \\
\hline Ignoreerimine & 58 & 58 & 0,031 & 0,976 \\
\hline
\end{tabular}

Märkus. ${ }^{1}$ - mitteparameetrilise $t$-testi väljastatud võrreldud rühmade keskmised, mis näitavad protsentides, kui paljud poistest ja tüdrukutest vastasid küsimusele "Kas see on kiusamine?" jaatavalt. 
Tabelist 7 ilmnebki, et poiste ja tüdrukute vastuste dünaamika oli liikide puhul sarnane. Kuigi liigiti poiste ja tüdrukute vahel erinevusi ei ilmnenud, tuleb siiski tähelepanu pöörata sellele, et teistest kiusamisliikidest eristub selgelt ignoreerimine, mida nii poisid kui ka tüdrukud on teiste kiusamisliikidega võrreldes harvem küberkiusamiseks nimetanud (vt tabel 7).

Analüüsides poiste ja tüdrukute hinnanguid küberkiusamise liikide tõsidusele, selgus, et poisid hindasid statistiliselt oluliselt sagedamini tõsisemaks kirjalik-verbaalset kiusamist (Manni-Whitney U-test; $z=-2,623$; $p<0,01)$. Ülejäänud liikide puhul soolist erinevust ei tuvastatud $(p>0,05)$. Lisaks andsid nii poisid kui ka tüdrukud tõsiduse puhul ignoreerimisele protsentides madalamaid hinnanguid (vt tabel 8).

Tabel 8. Poiste ja tüdrukute hinnangud stsenaariumite tõsidusele küberkiusamise liikide alusel

\begin{tabular}{l|c|c|c|c}
\hline Küberkiusamise liik & $\begin{array}{c}\text { Poisid } \\
\%^{1}\end{array}$ & $\begin{array}{c}\text { Tüdrukud } \\
\%^{1}\end{array}$ & z-statistik & $p$-väärtus \\
\hline Kirjalik-verbaalne kiusamine & 25 & 18 & $-2,623$ & $0,008^{* *}$ \\
\hline Privaatsuse rikkumine & 34 & 29 & $-0,834$ & 0,404 \\
\hline Visuaalne kiusamine & 36 & 30 & $-1,401$ & 0,161 \\
\hline Ignoreerimine & 18 & 10 & $-1,924$ & 0,054 \\
\hline
\end{tabular}

Märkused. ${ }^{* *}-p<0,01 .{ }^{1}$ - protsent poistest ja tüdrukutest, kelle hinnangute koondmediaan oli neljapallilisel skaalal suurem kui 2,5 ehk kelle hinnanguid loeti tõsiseks.

\section{Arutelu}

Uurimistöö eesmärk oli võrrelda poiste ja tüdrukute vahelisi erinevusi küberkiusamise fenomeni tajumisel kiusamise kriteeriumite ja liikide alusel. Esimesena sooviti leida vastus küsimusele, millised on poiste ja tüdrukute vahelised erinevused küberkiusamise fenomeni tajumisel, lähtudes küberkiusamise kriteeriumitest. Selgus, et 32 stsenaariumist ainult kahe (stsenaariumite 11 ja 18) puhul oli poiste ja tüdrukute vahel statistiliselt oluline erinevus $(p<0,05)$ : tüdrukud nimetasid neid stsenaariumeid sagedamini küberkiusamiseks kui poisid. Edasine analüüs agregeeritud andmestikuga kinnitas, et poisid ja tüdrukud tajuvad küberkiusamise fenomeni sarnaselt - poisid ei nimetanud küberkiusamise kriteeriumitest lähtudes stsenaariumeid oluliselt sagedamini küberkiusamiseks kui tüdrukud ja vastupidi. Sama tulemuseni jõudsid tavakiusamist uurides ka Smith jt (2002), kes leidsid, et poisid ja tüdrukud tajuvad kiusamist sarnaselt. 
Kuna varasemad küberkiusamise valdkonnas tehtud soolise võrdluse uuringud on näidanud üsna vastuolulisi tulemusi, on õigustatult tekkinud kahtlus, kas poiste jaoks on küberkiusamisel sama tähendus mis tüdrukute jaoks ja vastupidi. Siinkohal kerkib paratamatult esile ka uurimustes kasutatavate mõõtevahendite valiidsuse temaatika. Kuigi praeguste tulemuste üldistamisega tuleb metoodilistel põhjustel ettevaatlik olla, on need koos Smithi jt (2002) tavakiusamise kontekstis tehtud uuringu tulemustega kiusamiskäitumise uurijate jaoks julgustavad. Lisaks on varasema uurimuse seisukohalt (Naruskov et al., 2012) väga oluline tulemus see, et poiste ja tüdrukute hinnangutes ei ilmnenud erinevust kriteeriumite „tasakaalutus võimusuhetes” ja ,anonüümsus” puhul, sest just need kriteeriumid olid Eesti õpilaste arvates küberkiusamise põhikriteeriumid.

Küberkiusamise kriteeriumite võrdluses ilmnesid statistiliselt olulised erinevused poiste ja tüdrukute hinnangutes kriteeriumite tõsidusele. Täpsemalt olid poiste hinnangud tõsidusele kõrgemad 32 stsenaariumist kaheksal (stsenaariumid 9, 14, 15, 16, 17, 23, 28 ja 31). Agregeeritud andmestiku analüüsil selgus, et poiste hinnangud olid kõrgemad korduvuse, avalikkuse ja anonüümsuse kriteeriumi puhul. Küberkiusamine on kaudne kiusamisvorm, mistõttu peavad varasemad uurijad tõenäoliseks, et sellega on rohkem seotud tüdrukud (Slonje \& Smith, 2008; Willard, 2007). Mitmed uurimused on seda oletust ka kinnitanud (nt Beckman et al., 2013; Connell et al., 2014; Kowalski \& Limber, 2007). Kuna tüdrukutele on omased kaudsed kiusamisvormid (Nansel et al., 2001), siis võib põhjus, miks nende hinnangud tõsidusele olid oluliselt madalamad, seisneda selles, et stsenaariumites kirjeldatu oli nende jaoks tavapärane ning seetõttu mitte nii tõsine. Poistele, keda seostatakse pigem otsese (füüsilise) kiusamisega (Nansel et al., 2001), võisid ankeedis esitatud lood tunduda võõrana ja ka tõsisemana. Oletusele lisab kaalu asjaolu, et kolmest kriteeriumist, mille poisid tõsisemaks hindasid, kaks (avalikkus ja anonüümsus) on kriteeriumid, mida peetakse just küberkiusamisele omaseks (Menesini et al., 2012; Menesini \& Nocentini, 2009; Slonje \& Smith, 2008). Ka stsenaariumite puhul sisaldasid kaheksast stsenaariumist, milles poiste ja tüdrukute vahel statistiliselt oluline erinevus tuvastati, kuus avalikkuse kriteeriumit ning kaks anonüümsuse kriteeriumit. Osaliselt võib ilmnenud uurimistulemusi kõrvutada ka Friséni jt (2014) uurimusega, kus õpilastel paluti end panna küberkiusamise ohvri rolli ja ette kujutada, mis toimetulekustrateegiaid nad kasutaksid. Tulemused näitasid, et poisid reageeriksid küberkiusamisele oluliselt äkilisemalt kui tüdrukud. Nimelt nägid poisid kättemaksu tavaelus statistiliselt oluliselt sagedamini toimetulekustrateegiana kui tüdrukud, kes eelistaksid enda sõnul pigem kõrvalseisjate 
(õpetajate ja vanemate) teavitamist (Frisén et al., 2014). Seega tundub, et poiste reageeringud sellistele situatsioonidele on otsesemad ja äkilisemad, see omakorda võib olla põhjus, miks ka praegusel juhul olid poiste hinnangud küberkiusamise stsenaariumitele tõsisemad kui tüdrukutel.

Teisena otsiti uurimuses vastust küsimusele, millised on poiste ja tüdrukute vahelised erinevused küberkiusamise fenomeni tajumisel, lähtudes küberkiusamise liikidest. Küberkiusamise liikide andmeanalüüsist ilmnes, et poisid ei nimetanud ühtegi neljast küberkiusamise liigist (kirjalik-verbaalne kiusamine, visuaalne kiusamine, privaatsuse rikkumine, ignoreerimine) statistiliselt oluliselt sagedamini küberkiusamiseks kui tüdrukud ning vastupidi. Sama moodi nagu küberkiusamise kriteeriumite puhul, on ka see tulemus küberkiusamise mõõtmise seisukohalt oluline. Samas hindasid poisid kirjalik-verbaalset kiusamist statistiliselt oluliselt sagedamini tõsisemaks kui tüdrukud. Soolisi erinevusi võib kaudselt põhjendada sellega, et kirjalik-verbaalne kiusamine oli stsenaariumites väljendatud fraasiga, mis viitas otseselt kindla vahendi, täpsemalt tekstsõnumi kasutamisele kiusamisel („M. saatis solvava tekstsõnumi”). Slonje ja Smithi (2008) uuringu tulemusena selgus, et poisid olid tekstsõnumite vahendusel toimuva kiusamise puhul olnud statistiliselt oluliselt sagedamini kiusaja rollis kui tüdrukud. Seega võib oletada, et poisid hindasid kirjalik-verbaalset kiusamist tõsisemaks. Kuna nad kasutavad ka ise küberkiusamiseks tekstsõnumeid, oskavad nad paremini hinnata nende tõsidust ohvri jaoks. Samas peab järelduste tegemisega olema ettevaatlik, kuna Slonje ja Smithi (2008) uuring on tehtud Rootsi õpilastega. Seega ei saa kindlalt väita, et ka Eesti poisid kasutavad kiusamiseks kõige rohkem tekstsõnumeid ning hindavad seetõttu sellist kiusamist tõsisemaks. Paikapidavate järelduste tegemiseks vajab teema uurimist Eesti kontekstis.

Kuna mitmed uurimused näitavad, et küberkiusamisega on seotud pigem tüdrukud (nt Beckman et al., 2013; Connell et al., 2014; Kowalski \& Limber, 2007), siis soovitatakse ennetus- ja sekkumisprogrammide väljatöötamisel neile erilist tähelepanu pöörata (nt Connell et al., 2014). Siinse uurimistöö tulemustele tuginedes leiavad autorid, et poiste jätmine tagaplaanile pole õigustatud. Uurimistulemused näitasid, et poiste hinnangud tõsidusele olid tüdrukute omadest kolme küberkiusamise kriteeriumi ja ühe küberkiusamise liigi puhul kõrgemad. Seega võivad küberkiusamise ohvriks sattunud poisid toimuvat raskemini läbi elada. Eelnevale lisab kaalu ka asjaolu, et stsenaariumites 9, 14, 15, 16, 17 ja 23, mida poisid hindasid tõsisemaks kui tüdrukud, puudus kriteerium „tasakaalutus võimusuhetes". Kuigi tasakaalutuse puudumine võimusuhetes oli stsenaariumis väljendatud fraasiga „C. ei teinud sellest välja”, tajusid poisid ikkagi, 
et ohvri jaoks võib toimunu olla tõsine. Ka Frisén jt (2014) leiavad, et poisse ei saa ennetus- ja sekkumisprogrammide väljatöötamisel ning rakendamisel kergel käel kõrvale jätta. Poisse peab nii kodus (lapsevanemad) kui ka koolikeskkonnas (õpetajad ja klassijuhatajad) julgustama rääkima täiskasvanutele sellest, et nad on küberkiusamise ohvriks sattunud. Julgustamine on vajalik eeskätt seetõttu, et poisid kalduvad kasutama toimetulekustrateegiaid, mis võivad viia olukorrani, kus neist endist saavad kiusajad (Frisén et al., 2014).

\section{Kokkuvõte}

Selles uurimuses vaadeldi, kuidas poisid ja tüdrukud küberkiusamise fenomeni tajuvad. Küberkiusamise ennetamiseks ning selle probleemi tagajärgedega tegelemiseks on oluline teada, kuidas õpilased ise nähtust tajuvad. Küberkiusamise kontekstis on see teadmine tähtis ka seetõttu, et suurem osa lapsevanematest ja õpetajatest pole selle nähtusega oma kooliajal kokku puutunud. Uurimistulemused näitasid, et poisid ja tüdrukud tajusid küberkiusamise fenomeni sarnaselt: poisid ei nimetanud küberkiusamise kriteeriumitest ja liikidest lähtudes stsenaariumeid oluliselt sagedamini küberkiusamiseks kui tüdrukud ja vastupidi. See on oluline info küberkiusamise uurijatele, kes töötavad välja fenomeni mõõtmise instrumente. Kindlasti on see ka laiema üldsuse (sh lapsevanemate ja kooli) huvides, et meie laste ja noorte seas tehtavate uuringute metoodika oleks usaldusväärne. Uurimistulemused näitasid veel, et poisid ja tüdrukud tajusid küberkiusamise kriteeriumite ja liikide tõsidust erinevalt: poiste jaoks olid tõsisemad stsenaariumid, mis sisaldasid korduvuse, avalikkuse ja anonüümsuse kriteeriumit, lisaks hindasid nad tõsisemaks kirjalikverbaalse kiusamise. Mitmed uurijad on varem osutanud, et ühiskondlikud mõttemallid peegelduvad kübermaailmas ning nii kujutletaksegi tüdrukuid pigem ohvri ja poisse kiusajana (Frisén et al., 2014; Shariff, 2008). Praeguse uurimuse tulemused näitavad, kui oluline on nendest mõttemallidest lahti lasta. Stsenaariumid kõnetasid poisse ning nende hinnangul oli kirjeldatu tõsine. Võib arvata, et ka küberkiusamise ohvriks sattununa ei võta poisid seda nii kergelt, nagu esmapilgul võib tunduda. See teadmine osutab vajadusele töötada välja küberkiusamise ennetus- ja sekkumisprogrammid.

Eesti koolides propageeritakse järjest enam arvutite, interneti ja nutiseadmete kasutamist õppetöös. Tänapäeva digitaliseeritud ühiskonnas on see tavapärane ja tervitatav, sest peab ju koolist väljuv inimene kasvatuse 
ja õpetuse tulemusena saama hakkama ühiskonnas, kus ta elab. Kool ja õpetajad ei tohi aga ära unustada, et arvutite, interneti ja nutiseadmete kasutamisega peavad kaasnema ka juhised. Õpilased peavad teadma, mis on kübermaailmas lubatud ja mis mitte, kuidas kaitsta ennast ja teisi kübermaailmas varitsevate ohtude eest, kuidas küberkiusamisele reageerida jne. Seega on küberkiusamise kontekstis õpilaste digitaalse kirjaoskuse arendamine väga oluline.

Uurimuse piiranguna tuleb välja tuua valimi väiksuse ja seetõttu tulemuste üldistatavuse temaatika. Olulist teavet küberkiusamise fenomeni kohta oleks andnud stsenaariumite analüüsimine küberkiusamise liikide kaupa, kuid see polnud võimalik, kuna ankeedi täitja ei hinnanud stsenaariumeid 1-32 ühe liigi lõikes, st küsimustik oli kombineeritud neljast liigist. Samas oleks selline stsenaariumite haldamine teinud niigi suhteliselt suuremahulise ankeedi täitmise õpilastele üksluiseks ja igavaks. Võimaliku ohuna võib käsitleda ka seda, et uurijad ei olnud isiklikult kõigi küsimustike haldamise juures. Viimasena tuleb sarnaselt Pieschlile jt (2013) märkida, et ankeedis kasutatud stsenaariumid olid hüpoteetilised, mistõttu pole teada, kuivõrd saab neid üle kanda reaalsesse kiusamissituatsiooni, st kas õpilaste hinnangud küberkiusamise tõsidusele oleksid samasugused ka siis, kui nad on ise küberkiusamise ohvrid või kiusajad. Siiski võib stsenaariumite kasutamist pidada praegusel juhul õnnestunuks, kuna peale originaalsuse võimaldas see katta laia teoreetilise temaatika viie küberkiusamise kriteeriumi ja nelja küberkiusamise liigi näol.

Edasises uurimistöös peaks poiste ja tüdrukute võrdlemisel võtma arvesse ka nende võimalikku rolli kiusaja, ohvri ja kiusaja/ohvrina, sest see võib suuresti mõjutada, kuidas küberkiusamise fenomeni tajutakse. Lisaks on varasemad tavakiusamise uurimused näidanud, et vanuse kasvades suudetakse kiusamise nüansse paremini tabada (Smith et al., 2002). Siinses uurimuses vanuselistele erinevustele tähelepanu ei pööratud, kuid võimalik, et poiste ja tüdrukute võrdlemine vanuserühmiti annaks fenomeni sügavama mõistmise seisukohalt olulist teavet.

\section{Tänusõnad}

Uurimus valmis koostöös töörühmaga nr 1 COST IS0801 projekti „Cyberbullying: Coping with negative and enhancing positive uses of new technologies, in relationships in educational settings" raames. 


\section{Kasutatud kirjandus}

Ang, R. P., \& Goh, D. H. (2010). Cyberbullying among adolescents: The role of affective and cognitive empathy, and gender. Child Psychiatry and Human Development, 41(4), 387-397. doi: http://dx.doi.org/10.1007/s10578-010-0176-3

Beaton, D. E., Bombardier, C., Guillemin, F., \& Ferraz, M. B. (2000). Guidelines for the process of cross-cultural adaptation of self-report measures. Spine, 25(24), 3186-3191. doi: http://dx.doi.org/10.1097/00007632-200012150-00014

Beckman, L., Hagquist, C., \& Hellström, L. (2013). Discrepant gender patterns for cyberbullying and traditional bullying - An analysis of Swedish adolescent data. Computers in Human Behavior, 29(5), 1896-1903.

doi: http://dx.doi.org/10.1016/j.chb.2013.03.010

Berne, S., Frisén, A., Schultze-Krumbholz, A., Scheithauer, H., Naruskov, K., Luik, P., ... Žukauskienė, R. (2013). Cyberbullying assessment instruments: A systematic review. Aggression and Violent Behavior, 18(2), 320-334. doi: http://dx.doi.org/10.1016/j.avb.2012.11.022

Connell, N. M., Schell-Busey, N. M., Pearce, A. N., \& Negro, P. (2014). Badgrlz? Exploring sex differences in cyberbullying behaviors. Youth Violence and Juvenile Justice, 12(3), 209-228. doi: http://dx.doi.org/10.1177/1541204013503889

Dehue, F., Bolman, C., \& Völlink, T. (2008). Cyberbullying: Youngsters' experiences and parental perception. CyberPsychology \& Behavior: The Impact of the Internet, Multimedia and Virtual, 11(2), 217-223.

doi: http://dx.doi.org/10.1089/cpb.2007.0008

Dooley, J. J., Pyżalski, J., \& Cross, D. (2009). Cyberbullying versus face-to-face bullying: A theoretical and conceptual review. Zeitschrift Für Psychologie, 217(4), 182-188. doi: http://dx.doi.org/10.1027/0044-3409.217.4.182

Frisén, A., Berne, S., \& Marin, L. (2014). Swedish pupils' suggested coping strategies if cyberbullied: Differences related to age and gender. Scandinavian Journal of Psychology, 55(6), 578-584. doi: http://dx.doi.org/10.1111/sjop.12143

Gradinger, P., Strohmeier, D., \& Spiel, C. (2010). Definition and measurement of cyberbullying. Cyberpsychology, 4(2), 1-13.

Grigg, D. W. (2010). Cyber-aggression: Definition and concept of cyberbullying. Australian Journal of Guidance \& Counselling, 20(2), 143-156. doi: http://dx.doi.org/10.1375/ajgc.20.2.143

Gross, E. F., Juvonen, J., \& Gable, S. L. (2002). Internet use and well-being in adolescence. Journal of Social Issues, 58(1), 75-90. doi: http://dx.doi.org/10.1111/1540-4560.00249

Haddon, L., \& Livingstone, S. (2012). EU Kids Online: National perspectives. London: EU Kids Online, The London School of Economics and Political Science. Retrieved from http://eprints.lse.ac.uk/46878/

Hinduja, S., \& Patchin, J. W. (2008). Cyberbullying: An exploratory analysis of factors related to offending and victimization. Deviant Behavior, 29(2), 129-156. doi: http://dx.doi.org/10.1080/01639620701457816

Hinduja, S., \& Patchin, J. W. (2009). Bullying beyond the schoolyard: Preventing and responding to cyberbullying. Thousand Oaks, CA: Corwin Press. 
Juvonen, J., \& Gross, E. F. (2008). Extending the school grounds? - Bullying experiences in cyberspace. Journal of School Health, 78(9), 496-505. doi: http://dx.doi.org/10.1111/j.1746-1561.2008.00335.x

Kowalski, R. M., \& Limber, S. P. (2007). Electronic bullying among middle school students. Journal of Adolescent Health, 41(6), S22-S30. doi: http://dx.doi.org/10.1016/j.jadohealth.2007.08.017

Kowalski, R. M., Limber, S. P., \& Agatston, P. W. (2008). Cyber bullying: Bullying in the digital age. Malden, MA: Blackwell Publishing. doi: http://dx.doi.org/10.1002/9780470694176

Kumpulainen, K., Räsänen, E., \& Henttonen, I. (1999). Children involved in bullying: Psychological disturbance and the persistence of the involvement. Child Abuse \& Neglect, 23(12), 1253-1262.

doi: http://dx.doi.org/10.1016/S0145-2134(99)00098-8

Langos, C. (2012). Cyberbullying: The challenge to define. Cyberpsychology, Behavior, and Social Networking, 15(6), 285-289.

doi: http://dx.doi.org/10.1089/cyber.2011.0588

Li, Q. (2006). Cyberbullying in schools: A research of gender differences. School Psychology International, 27(2), 157-170. doi: http://dx.doi.org/10.1177/0143034306064547

Menesini, E., \& Nocentini, A. (2009). Cyberbullying definition and measurement: Some critical considerations. Zeitschrift Für Psychologie, 217(4), 230-232. doi: http://dx.doi.org/10.1027/0044-3409.217.4.230

Menesini, E., Nocentini, A., Palladino, B. E., Frisén, A., Berne, S., Ortega-Ruiz, R., ... Smith, P. K. (2012). Cyberbullying definition among adolescents: A comparison across six European countries. Cyberpsychology, Behavior, and Social Networking, 15(9), 455-463. doi: http://dx.doi.org/10.1089/cyber.2012.0040

Mesch, G. S. (2009). Parental mediation, online activities, and cyberbullying. Cyberpsychology \& Behavior: The Impact of the Internet, Multimedia and Virtual Reality on Behavior and Society, 12(4), 387-393. doi: http://dx.doi.org/10.1089/cpb.2009.0068

Mishna, F., Saini, M., \& Solomon, S. (2009). Ongoing and online: Children and youth's perceptions of cyber bullying. Children and Youth Services Review, 31(12), 1222-1228. doi: http://dx.doi.org/10.1016/j.childyouth.2009.05.004

Nansel, T. R., Overpeck, M., Pilla, R. S., Ruan, W. J., Simons-Morton, B., \& Scheidt, P. (2001). Bullying behaviors among US youth: Prevalence and association with psychosocial adjustment. JAMA: Journal of the American Medical Association, 285(16), 2094-2100. doi: http://dx.doi.org/10.1001/jama.285.16.2094

Naruskov, K., Luik, P., Nocentini, A., \& Menesini, E. (2012). Estonian students' perception and definition of cyberbullying. TRAMES: A Journal of the Humanities \& Social Sciences, 16(4), 323-343. doi: http://dx.doi.org/10.3176/tr.2012.4.02

Nocentini, A., Calmaestra, J., Schultze-Krumbholz, A., Scheithauer, H., Ortega, R., \& Menesini, E. (2010). Cyberbullying: Labels, behaviours and definition in three European countries. Australian Journal of Guidance and Counselling, 20(2), 129-142. doi: http://dx.doi.org/10.1375/ajgc.20.2.129

Olweus, D. (1999). Sweden. In P. K. Smith, Y. Morita, J. Junger-Tas, D. Olweus, R. Catalano, \& P. Slee (Eds.), The nature of school bullying: A cross-national perspective (pp. 7-27). London: Routledge. 
Olweus, D. (2011). Bullying at school and later criminality: Findings from three Swedish community samples of males. Criminal Behaviour and Mental Health: CBMH, 21(2), 151-156. doi: http://dx.doi.org/10.1002/cbm.806

Patchin, J. W., \& Hinduja, S. (2006). Bullies move beyond the schoolyard: A preliminary look at cyberbullying. Youth Violence and Juvenile Justice, 4(2), 148-169. doi: http://dx.doi.org/10.1177/1541204006286288

Pieschl, S., Porsch, T., Kahl, T., \& Klockenbusch, R. (2013). Relevant dimensions of cyberbullying - results from two experimental studies. Journal of Applied Developmental Psychology, 34(5), 241-252.

doi: http://dx.doi.org/10.1016/j.appdev.2013.04.002

Seals, D., \& Young, J. (2003). Bullying and victimization: Prevalence and relationship to gender, grade level, ethnicity, self-esteem, and depression. Adolescence, 38(152), 735-747.

Shariff, S. (2008). Cyber-bullying: Issues and solutions for the school, the classroom and the home. Abington: Routledge (Taylor \& Frances Group).

Slonje, R., \& Smith, P. K. (2008). Cyberbullying: Another main type of bullying? Scandinavian Journal of Psychology, 49(2), 147-154. doi: http://dx.doi.org/10.1111/j.1467-9450.2007.00611.x

Smith, P. K., Cowie, H., Olafsson, R. F., Liefooghe, A. P. D., Almeida, A., Araki, H., ... Wenxin, Z. (2002). Definitions of bullying: A comparison of terms used, and age and gender differences, in a fourteen-country international comparison. Child Development, 73(4), 1119-1133.

doi: http://dx.doi.org/10.1111/1467-8624.00461

Smith, P. K., Mahdavi, J., Carvalho, M., Fisher, S., Russell, S., \& Tippett, N. (2008). Cyberbullying: Its nature and impact in secondary school pupils. Journal of Child Psychology and Psychiatry, 49(4), 376-385. doi: http://dx.doi.org/10.1111/j.1469-7610.2007.01846.x

Snell, P. A., \& Englander, E. K. (2010). Cyberbullying victimization and behaviors among girls: Applying research findings in the field. Journal of Social Science, 6(4), 510-514. doi: http://dx.doi.org/10.3844/jssp.2010.510.514

Vaillancourt, T., McDougall, P., Hymel, S., Krygsman, A., Miller, J., Stiver, K., \& Davis, C. (2008). Bullying: Are researchers and children/youth talking about the same thing? International Journal of Behavioral Development, 32(6), 486-495. doi: http://dx.doi.org/10.1177/0165025408095553

Vandebosch, H., \& Van Cleemput, K. (2008). Defining cyberbullying: A qualitative research into the perceptions of youngsters. CyberPsychology \& Behavior: The Impact of the Internet, Multimedia and Virtual, 11(4), 499-503.

doi: http://dx.doi.org/10.1089/cpb.2007.0042

Willard, E. N. (2007). Cyberbullying and cyberthreats: Responding to the challenge of online social aggression, threats, and distress (2nd ed.). Champaign, IL: Research Press.

Ybarra, M. L., \& Mitchell, K. J. (2004). Youth engaging in online harassment: Associations with caregiver-child relationships, internet use, and personal characteristics. Journal of Adolescence, 27(3), 319-336.

doi: http://dx.doi.org/10.1016/j.adolescence.2004.03.007 


\section{Lisa 1}

Kriteeriumite kombineerimine stsenaariumites

\begin{tabular}{|c|c|c|c|c|c|}
\hline $\begin{array}{l}\text { Stse- } \\
\text { naarium }\end{array}$ & Tahtlikkus & Korduvus & $\begin{array}{c}\text { Tasakaalutus } \\
\text { võimusuhetes }\end{array}$ & Avalikkus & $\begin{array}{c}\text { Ano- } \\
\text { nüümsus }\end{array}$ \\
\hline 1 & EI & EI & EI & EI & EI \\
\hline 2 & EI & EI & JAH & EI & EI \\
\hline 3 & JAH & EI & JAH & EI & EI \\
\hline 4 & EI & JAH & JAH & EI & EI \\
\hline 5 & JAH & JAH & JAH & EI & EI \\
\hline 6 & JAH & EI & EI & EI & EI \\
\hline 7 & EI & JAH & EI & EI & EI \\
\hline 8 & JAH & JAH & EI & EI & EI \\
\hline 9 & EI & EI & EI & JAH & EI \\
\hline 10 & EI & EI & JAH & JAH & EI \\
\hline 11 & JAH & EI & JAH & JAH & EI \\
\hline 12 & EI & JAH & JAH & JAH & EI \\
\hline 13 & JAH & JAH & JAH & JAH & EI \\
\hline 14 & JAH & EI & EI & JAH & EI \\
\hline 15 & EI & JAH & EI & JAH & EI \\
\hline 16 & JAH & JAH & EI & $\mathrm{JAH}$ & EI \\
\hline 17 & EI & EI & EI & JAH & JAH \\
\hline 18 & EI & EI & JAH & $\mathrm{JAH}$ & JAH \\
\hline 19 & JAH & EI & JAH & JAH & JAH \\
\hline 20 & EI & JAH & JAH & JAH & JAH \\
\hline 21 & JAH & JAH & JAH & JAH & $\mathrm{JAH}$ \\
\hline 22 & JAH & EI & EI & JAH & JAH \\
\hline 23 & EI & JAH & EI & JAH & $\mathrm{JAH}$ \\
\hline 24 & JAH & JAH & EI & JAH & JAH \\
\hline 25 & EI & EI & EI & EI & JAH \\
\hline 26 & EI & EI & JAH & EI & JAH \\
\hline 27 & JAH & EI & JAH & EI & JAH \\
\hline 28 & EI & JAH & JAH & EI & JAH \\
\hline 29 & JAH & JAH & JAH & EI & JAH \\
\hline 30 & JAH & EI & EI & EI & JAH \\
\hline 31 & EI & JAH & EI & EI & JAH \\
\hline 32 & $\mathrm{JAH}$ & $\mathrm{JAH}$ & EI & EI & $\mathrm{JAH}$ \\
\hline
\end{tabular}

Märkus. EI - kriteeriumi puudumine stsenaariumist; JAH - kriteeriumi olemasolu stsenaariumis. 


\title{
The perception of the cyberbullying phenomenon among Estonian students: Comparison of boys and girls on the basis of cyberbullying criteria and types of behaviour
}

\author{
Karin Naruskov ${ }^{a 1}$, Piret Luik ${ }^{\mathbf{a}}$ \\ a University of Tartu, Institute of Educational Sciences
}

\section{Summary}

\section{Introduction}

With the rapid change in forms of communication bullying through electronic devices has emerged. „Cyberbullying is an aggressive, intentional act carried out by a group or individual, using electronic forms of contact, repeatedly, and over time against a victim who cannot easily defend him or herself" (Smith et al., 2008, p. 376). This definition emphasises the three Olweus' (1999) bullying criteria (intentionality, repetition, and imbalance of power). In addition, it identifies the electronic environment where cyberbullying occurs. Electronic communication has its own peculiarities. On the one hand, communication in cyber context is entirely public in nature because it involves large numbers of people who are given the opportunity to witness, contribute, or fight against, to what is happening online (Kowalski \& Limber, 2007). On the other hand, computer mediated communication creates the illusion of anonymity without difficulty because it is easy to create anonymous avatars and personas there (Kowalski et al., 2008; Kowalski \& Limber, 2007; Shariff, 2008; Willard, 2007). To sum up, it is assumed that there may be some other criteria in addition to the Olweus' criteria, such as publicity and anonymity which may be more specific in the cyber context (Menesini et al., 2012; Menesini \& Nocentini, 2009; Slonje \& Smith, 2008).

Previous researchers have attempted to categorise different types of cyberbullying behaviour into a more compact list (Nocentini et al., 2010; Willard, 2007). On the basis of Willard (2007), Nocentini et al. (2010) summarised different categories of cyberbullying behaviour into four main typologies based on the nature of the attack: written-verbal behaviours,

Institute of Educational Sciences, Faculty of Social Sciences and Education, University of Tartu, Salme 1a, 50103 Tartu, Estonia; karin.naruskov@ut.ee 
visual behaviours, impersonation, and exclusion. Nocentini et al. (2010) and Naruskov et al. (2012) have described these four typologies in greater detail.

Research results about cyberbullying in the context of gender differences are characterised by inconsistency. Many studies have come to the conclusion that girls are more involved in cyberbullying as victims (Dehue et al., 2008; Mesch, 2009; Smith et al., 2008), or they can be both victims and bullies (Beckman et al., 2013; Connell, 2014; Kowalski \& Limber, 2007). On the contrary, Li (2006) found that boys are more involved with cyberbullying behaviours as bullies as compared to girls. In addition, some studies have not found any differences between boys and girls in this respect (Hinduja \& Patchin, 2008; Patchin \& Hinduja, 2006; Smith et al., 2008). All things considered, it can be further argued whether the different cyberbullying experiences of the boys and girls may be due to the fact that they perceive (or they have been taught to perceive) the virtual environment and the bullying that goes on there differently. Similarly, in the context of traditional bullying Smith et al. (2002) speculated that there may be differences on how bullying is perceived by boys and girls. The result of their research showed that there were no significant gender differences on how the term bullying is perceived by boys and girls (Smith et al., 2002). Nevertheless, this issue should also be examined in the context of cyberbullying because it is necessary to know whether there are differences on how boys and girls perceive cyberbullying behaviour to gain a deeper understanding of the phenomena and to provide preliminary input to definition and instrumentation development.

The aim of this study was to compare Estonian boys' and girls' perception of cyberbullying on the basis of the five cyber-bullying criteria (imbalance of power, intention, repetition, anonymity, and publicity/privacy) and four types of cyberbullying behaviour (written-verbal, visual, exclusion, and impersonation). This study aimed to address the following research questions:

1) What are the differences between Estonian boys' and girls' perception of the cyberbullying phenomenon in the context of five cyberbullying criteria?

2) What are the differences between boys' and girls' perception of the cyberbullying phenomenon in the context of four cyberbullying types?

\section{Methodology}

The sample consisted of 336 (163 girls and 173 boys) Estonian students from six basic schools and six secondary schools. The schools were chosen 
on the basis of convenience sampling method. The age of the participants ranged from 11 to 17 years $(\mathrm{M}=14.04 ; \mathrm{SD}=1.46)$. The data were collected through anonymous questionnaires distributed in the classrooms during a school day in between February and May 2011.

The questionnaire used in this study was developed within the framework of the European project COST Action IS0801 by working group one (see also Naruskov et al., 2012; Menesini et al., 2012). In the set of the 32 scenarios the presence and absence of five cyberbullying criteria were combined across four types of cyberbullying behaviour (see Table 2 and Appendix 1). Thus, in total there were 128 scenarios developed. Four versions of questionnaires were created; each included 32 scenarios divided equally between the four types of cyberbullying behaviour (see Table 3). The four versions together included the complete set of the scenarios and were administrated randomly to the participants. In the context of all presented scenario participants were asked to a) evaluate whether they considered the scenario bullying or not, and b) if they answered yes, the next step was to evaluate the seriousness of the scenario from the victim's point of view (a bit serious, quite serious, serious, very serious). The validity of the questionnaire was confirmed by the panel of European experts from COST ACTION IS0801 and the instrument was pre-tested. For further information see also Naruskov et al., 2012; Menesini et al., 2012. Firstly, scenarios 1-32 were analysed separately. Secondly, the scenarios were aggregated on the basis of the five cyberbullying criteria; the percentages of „yes, it is cyberbullying" were calculated with the scenarios with presence one of the five cyberbullying criteria. The aggregation process was repeated on the basis of the type of cyberbullying behaviour; percentages of "yes, it is cyber-bullying" were computed for each type of cyberbullying behaviour. In the context of severity, medians were calculated from the aggregate data. Chi-square test, Independent Samples T-Test, and Mann-Whitney U test were used in order to analyse the data.

\section{Results and discussion}

This study concentrated on Estonian boys' and girls' perception of cyberbullying. The data analysis separately for scenarios 1 to 32 revealed only two statistically significant differences (see Diagram 1). Girls evaluated scenarios 11 and 18 as cyberbullying more often than their male counterparts (see Appendix 1). This result was also supported by the data analysis with the aggregated data. More precisely, in the context of cyber- 
bullying criteria we found no statistically significant gender differences on how the boys and the girls named scenarios as cyberbullying; the boys' and the girls' evaluations were similar all across five cyber-bullying criteria (see Table 5). The results were similar across the types of cyberbullying behaviour as well; the boys did not name any of the four types of cyberbullying behaviour as cyber-bullying more often than the girls (see Table 7). These results are inconsistent with the previous research in the field of traditional bullying (Smith et al., 2002) which showed that there were no larger gender differences on how the term bullying was perceived by boys and girls. Since the research results about cyberbullying in the context of gender differences are characterised by inconsistency, the question arises whether the phenomenon is perceived similarly by boys and girls. Consequently, this topic is crucial when one wants to develop valid instruments to measure cyberbullying behaviour. Although we must be cautious about making generalisations from our results on larger populations, we may still conclude that our study results together with Smith et al. (2002) provide some assurance for scientists who are engaged in examining the phenomenon of cyber-bullying.

Significant gender differences were identified in terms of severity evaluations across cyber-bullying criteria and type of cyber-bullying behaviour. The data analysis separately for scenarios 1-32 revealed that the boys evaluated scenarios $9,14,15,16,17,23,28$, and 31 more serious than the girls (see Appendix 1). In the case of aggregated data, the boys' evaluated scenarios with the presence of repetition, publicity, and anonymity criterion more seriously than their female counterparts (see Table 6). In the context of type of cyber-bullying behaviour the boys' severity evaluations were higher for the written-verbal scenarios (see Table 8). Previous studies have shown that cyber-bullying as an indirect form of bullying is more typical for girls and not typical for boys who engage in more as perpetrators of direct forms of bullying (Nansel et al., 2001). Given these considerations we may assume that for the girls the situations in scenarios were familiar and consequently not so serious. The boys' severity evaluations were higher because they are not accustomed to such behaviour. Consequently we may hypothesise that the boys who are engaged with cyberbullying behaviour as victims may feel devastated because of what is happening. These results are important inputs for the development of cyberbullying prevention and intervention programmes.

Keywords: cyberbullying criteria, types of cyberbullying, perception, gender differences 


\section{Appendix 1}

Presence $(\mathrm{Y})$ and absence $(\mathrm{N})$ of the criteria for all 32 scenarios

\begin{tabular}{|c|c|c|c|c|c|}
\hline Scenario & $\begin{array}{c}\text { Intentio- } \\
\text { nality }\end{array}$ & Repetition & $\begin{array}{l}\text { Imbalance } \\
\text { of power }\end{array}$ & Publicity & Anonymity \\
\hline 1 & $\mathrm{~N}$ & $\mathrm{~N}$ & $\mathrm{~N}$ & $\mathrm{~N}$ & $\mathrm{~N}$ \\
\hline 2 & $\mathrm{~N}$ & $\mathrm{~N}$ & $\mathrm{Y}$ & $\mathrm{N}$ & $\mathrm{N}$ \\
\hline 3 & $\mathrm{Y}$ & $\mathrm{N}$ & $\mathrm{Y}$ & $\mathrm{N}$ & $\mathrm{N}$ \\
\hline 4 & $\mathrm{~N}$ & $\mathrm{Y}$ & $\mathrm{Y}$ & $\mathrm{N}$ & $\mathrm{N}$ \\
\hline 5 & $\mathrm{Y}$ & $\mathrm{Y}$ & $\mathrm{Y}$ & $\mathrm{N}$ & $\mathrm{N}$ \\
\hline 6 & $\mathrm{Y}$ & $\mathrm{N}$ & $\mathrm{N}$ & $\mathrm{N}$ & $\mathrm{N}$ \\
\hline 7 & $\mathrm{~N}$ & $\mathrm{Y}$ & $\mathrm{N}$ & $\mathrm{N}$ & $\mathrm{N}$ \\
\hline 8 & $\mathrm{Y}$ & $\mathrm{Y}$ & $\mathrm{N}$ & $\mathrm{N}$ & $\mathrm{N}$ \\
\hline 9 & $\mathrm{~N}$ & $\mathrm{~N}$ & $\mathrm{~N}$ & $\mathrm{Y}$ & $\mathrm{N}$ \\
\hline 10 & $\mathrm{~N}$ & $\mathrm{~N}$ & $\mathrm{Y}$ & $\mathrm{Y}$ & $\mathrm{N}$ \\
\hline 11 & $\mathrm{Y}$ & $\mathrm{N}$ & $\mathrm{Y}$ & $\mathrm{Y}$ & $\mathrm{N}$ \\
\hline 12 & $\mathrm{~N}$ & $\mathrm{Y}$ & $\mathrm{Y}$ & $\mathrm{Y}$ & $\mathrm{N}$ \\
\hline 13 & $\mathrm{Y}$ & $\mathrm{Y}$ & $\mathrm{Y}$ & $\mathrm{Y}$ & $\mathrm{N}$ \\
\hline 14 & $\mathrm{Y}$ & $\mathrm{N}$ & $\mathrm{N}$ & $\mathrm{Y}$ & $\mathrm{N}$ \\
\hline 15 & $\mathrm{~N}$ & $\mathrm{Y}$ & $\mathrm{N}$ & $\mathrm{Y}$ & $\mathrm{N}$ \\
\hline 16 & $\mathrm{Y}$ & $\mathrm{Y}$ & $\mathrm{N}$ & $\mathrm{Y}$ & $\mathrm{N}$ \\
\hline 17 & $\mathrm{~N}$ & $\mathrm{~N}$ & $\mathrm{~N}$ & $\mathrm{Y}$ & $\mathrm{Y}$ \\
\hline 18 & $\mathrm{~N}$ & $\mathrm{~N}$ & $\mathrm{Y}$ & $\mathrm{Y}$ & $\mathrm{Y}$ \\
\hline 19 & $\mathrm{Y}$ & $\mathrm{N}$ & $\mathrm{Y}$ & $\mathrm{Y}$ & $\mathrm{Y}$ \\
\hline 20 & $\mathrm{~N}$ & $\mathrm{Y}$ & $\mathrm{Y}$ & $\mathrm{Y}$ & $\mathrm{Y}$ \\
\hline 21 & $\mathrm{Y}$ & $\mathrm{Y}$ & $\mathrm{Y}$ & $\mathrm{Y}$ & $\mathrm{Y}$ \\
\hline 22 & $\mathrm{Y}$ & $\mathrm{N}$ & $\mathrm{N}$ & $\mathrm{Y}$ & $\mathrm{Y}$ \\
\hline 23 & $\mathrm{~N}$ & $\mathrm{Y}$ & $\mathrm{N}$ & $\mathrm{Y}$ & $\mathrm{Y}$ \\
\hline 24 & $\mathrm{Y}$ & $\mathrm{Y}$ & $\mathrm{N}$ & $\mathrm{Y}$ & $\mathrm{Y}$ \\
\hline 25 & $\mathrm{~N}$ & $\mathrm{~N}$ & $\mathrm{~N}$ & $\mathrm{~N}$ & $\mathrm{Y}$ \\
\hline 26 & $\mathrm{~N}$ & $\mathrm{~N}$ & $\mathrm{Y}$ & $\mathrm{N}$ & $\mathrm{Y}$ \\
\hline 27 & $\mathrm{Y}$ & $\mathrm{N}$ & $\mathrm{Y}$ & $\mathrm{N}$ & $\mathrm{Y}$ \\
\hline 28 & $\mathrm{~N}$ & $\mathrm{Y}$ & $\mathrm{Y}$ & $\mathrm{N}$ & $\mathrm{Y}$ \\
\hline 29 & $\mathrm{Y}$ & $\mathrm{Y}$ & $\mathrm{Y}$ & $\mathrm{N}$ & $\mathrm{Y}$ \\
\hline 30 & $\mathrm{Y}$ & $\mathrm{N}$ & $\mathrm{N}$ & $\mathrm{N}$ & $\mathrm{Y}$ \\
\hline 31 & $\mathrm{~N}$ & $\mathrm{Y}$ & $\mathrm{N}$ & $\mathrm{N}$ & $\mathrm{Y}$ \\
\hline 32 & $\mathrm{Y}$ & $\mathrm{Y}$ & $\mathrm{N}$ & $\mathrm{N}$ & $\mathrm{Y}$ \\
\hline
\end{tabular}

Comment. $\mathrm{N}$ - absence of criteria in the scenario, $\mathrm{Y}$ - presence of criteria in the scenario. 